\title{
IMPACT OF ARBUSCULAR MYCORRHIZAL FUNGI ON SOME DEFENSE ENZYME ACTIVITIES AT AN EARLY STAGE OF MAIZE (ZEA MAYS. L) UNDER DIFFERENT ABIOTIC STRESSES
}

\author{
MAYER, Z. ${ }^{1}$ - JUHÁSZ, Á. ${ }^{1}-$ VO TRUNG, A. ${ }^{1}-$ POSTA, K. ${ }^{1,2^{*}}$ \\ ${ }^{1}$ Institute of Genetics, Microbiology and Biotechnology, Szent István University \\ Páter Károly u. 1, Gödöllö 2100, Hungary \\ (phone: +36-28-522-000) \\ ${ }^{2}$ Industrial University of Ho Chi Minh City, 12 Nguyen Van Bao Street \\ Ho Chi Minh City, Vietnam \\ *Corresponding author \\ e-mail:posta.katalin@mkk.szie.hu; phone:+36-28-522-000/ext.2105 \\ (Received $1^{\text {st }}$ Dec 2018; accepted $14^{\text {th }}$ Feb 2019)
}

\begin{abstract}
Environmental impacts on plants are becoming more extreme and their response to these effects is a key factor in plant production. Promoting the adaptability of plants is a priority area, one of the opportunities is the symbiotic system of mycorrhizal fungi with plants. Arbuscular mycorrhizal (AM) fungi have beneficial effects on plants' water and nutrient uptake and increasing plant defense mechanisms to alleviate different oxidative stresses. The aim of this study was to investigate how arbuscular mycorrhizal fungi influence the changes in some plant defense enzymes (catalase (CAT), peroxidase (PER), glutathione S-transferase (GST), polyphenol oxidase (PPO)) together with gene expressions under salt, high temperature and drought stresses at an early stage of maize (Zea mays L.). The results suggest that AM fungi inoculation may take part in the alleviation processes caused by high temperature, salt and drought stresses. However, these mechanisms are influenced by the age of the plants which is most likely justified by energy considerations.
\end{abstract}

Keywords: drought stress, salinity stress, AM fungi inoculation, peroxidase, catalase

\section{Introduction}

Maize (Zea mays L.) is one of the most important widely grown crops. According to the latest statistical data on maize growing in Hungary, the total harvested area and output was 0.99 Mha and $6.8 \mathrm{Tg}$ in 2017. Several studies show the dramatically negative impact of climate change on crop production, and similar trend can be found in Hungarian maize production caused by the frequency of extreme agrometeorological phenomenous (Nagy, 2010; Lobell et al., 2012; Pepó and Vári, 2016). However only few works have been done at an early stage, where plants not yet adapted to these conditions. Various biotic and abiotic stresses such as salt, extreme temperature and drought are the most limiting factors on plant growth and decrease crop yield (Molazem and Azimi, 2015). Under stress conditions highly reactive oxygen species (ROS) are generated in plant and ROS-scavenging enzymes (catalase, peroxidase, glutathione S-transferase etc.) together with non-enzymatic way (ascorbic acid, glutathione etc.) are able to detoxify these toxic molecules (Choudhury et al., 2017). Several studies have reported changes in defense enzyme activities and transcriptional alterations of maize under different stress conditions such as drought (Chugh et al., 2011; Song et al., 2017; Zenda et al., 2018), temperature (Zhu et al., 2010; Cetinkaya et al., 2014; Shi et al., 2017), salinity (Estrada et al., 2013; Carrasco-Ríos and Pinto, 2014; AbdElgawad et al., 2016; Forieri et al., 2016). There are some opportunities including the inoculation with 
arbuscular mycorrhizal (AM) fungi for helping the plants to tolerate extreme environmental conditions and alleviate reactive oxygen species. This symbiotic relationship has established more than 400 million years ago and offer some benefits to target plant, including enhanced uptake of water and nutrients - mostly phosphorus - as well as reduction of weeds and protection against pathogens (Feddermann et al., 2010; Ruiz-Sánchez et al., 2010; Smith et al., 2011; Smith and Smith, 2011; Bowles et al., 2016). Several studies suggest that AM fungi induce a plant-wide systemic defense mechanism called mycorrhiza-induced resistance (MIR) (Cameron et al., 2013; Dehghan et al., 2013). The MIR is associated with a more effective activation of JA-dependent system helping plants to alleviate various biotic and abiotic stresses (Chen et al., 2013; Anjum et al., 2016). However, the increased resistance caused by AM fungi is dependent on plant species, arbuscular mycorrhizal fungi and environmental conditions (Pozo and Azcón-Aguilar, 2007; Azcón and Barea, 2010; Vos et al., 2013). Some studies clearly suggest that amelioration of stress resistance by AM fungi symbiosis related to the raising of antioxidant activities in colonized plants (Hajiboland et al., 2010; Baslam and Goicoechea, 2012; Abdel Latef, 2013; Liu et al., 2015; Păun et al., 2015). The mechanisms by which AM fungi alter the production of defense enzymes are still not clarified and only few studies have been carried out at an early stage of plants concerning low level of mycorrhizal colonization.

Therefore, our aim was to investigate how arbuscular mycorrhizal fungi influence the changes in some plant defense enzymes together with gene expressions (catalase $(C A T)$, peroxidase $(P E R)$, glutathione S-transferase $(G S T)$, polyphenol oxidase $(P P O))$ under salt, high temperature and drought stresses at an early stage of maize (Zea mays L.).

\section{Materials and methods}

\section{Plant material and growth conditions}

The experiment was carried out in Institute of Genetics, Microbiology and Biotechnology, Szent István University (SZIU), Gödöllő, Pest County, Hungary. Seeds of maize ('Golda F1') were sterilized in $1 \% \mathrm{NaOCl}$ then washed with sterilized water five times and germinated on wet filter paper. Three days after germination the seedlings were transferred to plastic pots containing $0.75 \mathrm{~kg}$ sterilized peat and sand 1:2 (v/v) as substrate. Half of the transplanted plants were inoculated with $15 \mathrm{~g}$ of a commercial mycorrhizal product, Symbivit ${ }^{\circledR}$ (mixture of Rhizophagus irregularis, Funneliformis mosseae, Claroideoglomus etunicatum, Claroideoglomus claroideum, G. microaggregatum, Funneliformis geosporum) produced by Symbiom Ltd. (Lanskroun, Czech Republic; www.symbiom.cz). For non-mycorrhizal treatments sterilized mycorrhizal inoculant were prepared at the same rate $\left(15 \mathrm{~g} \mathrm{plot}^{-1}\right)$ and were then used in mycorrhizal treatment. Both treatments were transferred to a climatic chamber EKOCHL $1500\left(24 / 26^{\circ} \mathrm{C}, 60 \% \mathrm{RH}, 16 \mathrm{~h}\right.$ light $/ 8 \mathrm{~h}$ dark $)$ for 21 or 42 days. Plants (mycorrhizal and non-mycorrhizal) were exposed to different stress conditions. Plants were irrigated daily with $25 \mathrm{ml}$ of $100 \mathrm{mM} \mathrm{NaCl}$, representing salinity stress. Additional plants were exposed to drought stress (FC $20 \pm 5 \%$ ) compared to control (FC $85 \pm 3 \%$ ). Healthy 20 and 41 days-old seedlings were selected and exposed to $42^{\circ} \mathrm{C}$ for $24 \mathrm{~h}$ as high temperature stress (HT). Altogether eight treatments with two harvest time were designed replicated five times: 21 or 42 days old mycorrhizal inoculated plants (+AM) and non-mycorrhizal plants (-AM) under salt (Salt), high temperature 
(HT), drought (D) and control (C) conditions, respectively. Plants were harvested after 21 or 42 days of growth, fresh and dry weight of shoots and roots were estimated.

\section{$R N A$ isolation and $c D N A$ synthesis}

Total RNA was extracted from maize leaves using Vantage Total RNA Purification Kit (Origene, USA) following the manufacturer's instructions, followed by DNase I (Fermentas) digestion the genomic DNA in the total RNA was eliminated. For qRT-PCR analysis from all treatments first-strand cDNA was synthesized using First-Strand cDNA Synthesis for Quantitative RT-PCR kit (Origene, USA). QRT-PCR was performed on Stratagene Mx3000P QPCR System (Agilent Technologies). Each reaction was performed in a final volume of $25 \mu$ l containing $12.5 \mu \mathrm{l}$ SYBR Green Master Mix reagent (Applied Biosystems), $1 \mu \mathrm{l}$ of diluted cDNA sample (equal concentration in final volume, $4 \mathrm{ng} / \mu \mathrm{l}), 70 \mathrm{nM}$ gene-specific primers and $8 \mu \mathrm{l}$ nucleasefree water. Gene-specific primers sequences listed in Table 1.

Table 1. Primers for $q R T-P C R$ analysis

\begin{tabular}{c|c|c}
\hline Gene & Primer set (5' to 3') & Product size (bp) \\
\hline catalase $(C A T)$ & $\begin{array}{c}\text { forward: ATCAAGTTCCCCGACGTGATCC } \\
\text { reverse: AGAAGAAGGTGTGCAGGCTCTC }\end{array}$ & 118 \\
\hline peroxidase $(P E R)$ & $\begin{array}{c}\text { forward: CGCCTCCAAGAACCTCAGTATC } \\
\text { reverse: AGTTGTAGAGCCGGTCAACG }\end{array}$ & 128 \\
\hline polyphenol oxidase $(P P O)$ & $\begin{array}{c}\text { forward: ATCTTCTTCCCGCACCACAC } \\
\text { reverse: TCCTCGTCGTAGAACAGGAACG } \\
\text { glutathione S-transferase }(G S T)\end{array}$ & $\begin{array}{c}125 \\
\text { forward: ACCGACTCGTTGCCTACTTCAC }\end{array}$ \\
\hline \multirow{2}{*}{ actin } & $\begin{array}{c}\text { forward: CAGTGGTCGAACAACGGGTA } \\
\text { reverse: GGTAAGGTCACGACCAGCAA }\end{array}$ & 105 \\
\hline
\end{tabular}

PCR cycle procedure was: $95^{\circ} \mathrm{C}$ for $15 \mathrm{~min}$, followed by 40 cycles at $95^{\circ} \mathrm{C}$ for $15 \mathrm{sec}, 58^{\circ} \mathrm{C}$ for $30 \mathrm{sec}$ and $72^{\circ} \mathrm{C}$ for $16 \mathrm{sec}$, finally $1 \mathrm{cycle}$ at $95^{\circ} \mathrm{C} 60 \mathrm{sec}, 58^{\circ} \mathrm{C} 30 \mathrm{sec}$ and $95^{\circ} \mathrm{C} 30 \mathrm{sec}$. The real-time PCR experiment was conducted under identical conditions with three replications. As internal reference amplification of actin gene was used (Table 1). The gene expression of CAT, PER, GST, PPO was calculated using the $2^{-\Delta \Delta \mathrm{CT}}$ method.

\section{Enzyme assays}

In order to determine the enzyme activity of PER and PPO plant extract was prepared using $0.2 \mathrm{~g}$ fresh plant leaves in Tris-HCl $(3 \mathrm{ml} ; 50 \mathrm{mM} ; \mathrm{pH} 7.8)$; polyvinylpyrrolidone-K $25(7.5 \%(\mathrm{w} / \mathrm{v})$ and EDTA-Na $2(1 \mathrm{mM}))$ buffer. Peroxidase enzyme activities are performed by Rathmell and Sequeira (1974), the change in absorbance is observed at $436 \mathrm{~nm}$ wavelength. For the measurement, $1.1 \mathrm{ml}$ of $0.1 \mathrm{M}$ sodium phosphate buffer solution ( $\mathrm{pH} 6.0$ ), $50 \mu \mathrm{l}$ of $50 \mathrm{mM}$ guaiacol, $50 \mu \mathrm{l}$ of $12 \mathrm{mM}$ hydrogen peroxide, and $5 \mu \mathrm{l}$ of plant extract were added to the reaction mixture. The concentration of polyphenol oxidase enzyme - more specifically the degree of the formation of quinone compounds - was carried out by Fehrmann and Dimond (1967). 
The change in absorbance was monitored at $400 \mathrm{~nm}$ for 10 minutes. The reaction mixture contained $1.1 \mathrm{ml}$ of buffer solution and $100 \mu \mathrm{l}$ of plant extract. The buffer solution was prepared by adding $0.1 \mathrm{M}$ sodium phosphate buffer ( $\mathrm{pH}$ 6.0), 1 mM EDTA and $20 \mathrm{mM}$ catechol. Plant extract for CAT and GST protocol was prepared using $0.2 \mathrm{~g}$

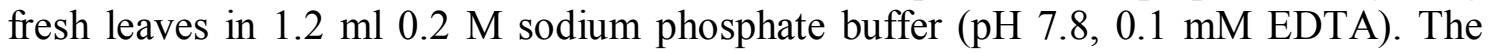
catalase enzyme activity was measured by the method of Aebi (1984), based on the dissociation ability of hydrogen peroxide. For measuring $995 \mu \mathrm{l}$ of $50 \mathrm{mM}$ sodium

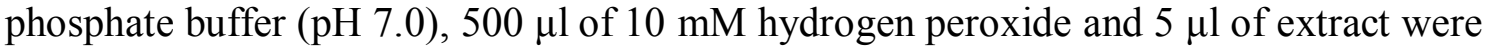
mixed. The change of absorbance was followed at $240 \mathrm{~nm}$ wavelength for 5 minutes. Glutathione S-transferase enzyme activities were measured using Glutathione S-transferase (GST) Assay Kit (Sigma-Aldrich-Merck, Darmstadt, Germany) established on the method of Habig et al. (1974). The concentration of total soluble protein in plant extract solution was determined using Bradford reagent, bovine serum albumin as a standard (Bradford, 1976).

\section{Assessment of mycorrhizal colonization of AM fungi}

Root colonization was estimated in five plants both from mycorrhizal and nonmycorrhizal per treatments. Fine roots from each plant were stained with Trypan Blue (Vierheilig et al., 1998). Stereomicroscope at $\times 100$ magnification was used to examine the internal fungal structures (hyphae, arbuscules) and the percentage of root colonization was calculated using grid line intersect method (Giovannetti and Mosse, 1980).

\section{Statistical analysis}

Statistical analysis was performed with R Statistical Software 3.3.1 (R Development Core Team, 2011). Values were expressed as means \pm SD. Differences between treatments were determined by one-way analysis of variance (ANOVA). A $p$-value $<0.05$ was considered to indicate statistical significance.

\section{Results and discussion}

No colonization was recognized when sterilized inoculant were used for inoculation. 21 days after AM fungi inoculation, external hyphae together with germinated spores were only detected, however internal hyphae together with arbuscules were recorded at older age of plants. The highest level of mycorrhizal colonization $(52 \% \pm 4)$ was measured after 6 weeks of growth under drought stress following under high temperature $(42 \% \pm 2)$ and salt stresses $(35 \% \pm 3)$, respectively.

Significant differences in fresh shoots and roots weights were observed in arbuscular mycorrhizal inoculated plants under control conditions and high temperature stresses. Drought and salt stress reduced the biomass of AM fungi inoculated and nonmycorrhizal plants, as well. Generally, lower biomass production of plants caused by drought and salt stress is associated with inhibition of leaf development and consequently reduced light interception (Anjum et al., 2011; Kaya et al., 2013a). The mycorrhizal inoculated salt treated plants did not show statistical difference in the shoot and root biomass compared to the non-mycorrhizal ones. Under drought conditions only the root biomass was affected by mycorrhizal colonisation after 21 days of growth (Table 2). 
Table 2. Biomass of mycorrhizal ( $+A M)$ and non-mycorrhizal (-AM) plants after 21 days of growth

\begin{tabular}{cc|cc|cc}
\hline \multicolumn{2}{c|}{ Age of plant 21 days } & \multicolumn{2}{c|}{ Shoots } & \multicolumn{2}{c}{ Roots } \\
\hline \multirow{2}{*}{ Treatments } & & $\begin{array}{c}\text { Fresh weight } \\
(\mathrm{g} \text { plant }\end{array}$ & $\begin{array}{c}\text { Dry weight } \\
\left(\mathrm{g} \mathrm{plant}^{-1}\right)\end{array}$ & $\begin{array}{c}\text { Fresh weight } \\
\left(\mathrm{g} \mathrm{plant}^{-1}\right)\end{array}$ & $\begin{array}{c}\text { Dry weight } \\
(\mathrm{g} \mathrm{plant})\end{array}$ \\
\hline \multirow{2}{*}{ Control (C) } & -AM & $1.58 \pm 0.05 \mathrm{~b}$ & $0.58 \pm 0.12 \mathrm{~b}$ & $0.68 \pm 0.18 \mathrm{c}$ & $0.34 \pm 0.08 \mathrm{~b}$ \\
& $+\mathrm{AM}$ & $1.76 \pm 0.07 \mathrm{c}$ & $0.82 \pm 0.07 \mathrm{c}$ & $0.97 \pm 0.06 \mathrm{~d}$ & $0.72 \pm 0.10 \mathrm{c}$ \\
\hline \multirow{2}{*}{ Salt (S) } & $-\mathrm{AM}$ & $0.42 \pm 0.06 \mathrm{a}$ & $0.19 \pm 0.08 \mathrm{a}$ & $0.12 \pm 0.03 \mathrm{a}$ & $0.07 \pm 0.01 \mathrm{a}$ \\
& $+\mathrm{AM}$ & $0.50 \pm 0.07 \mathrm{a}$ & $0.25 \pm 0.09 \mathrm{a}$ & $0.25 \pm 0.05 \mathrm{ab}$ & $0.10 \pm 0.02 \mathrm{a}$ \\
\hline \multirow{2}{*}{ High temperature (HT) } & -AM & $1.57 \pm 0.05 \mathrm{~b}$ & $0.57 \pm 0.10 \mathrm{~b}$ & $0.66 \pm 0.04 \mathrm{c}$ & $0.30 \pm 0.03 \mathrm{~b}$ \\
& $+\mathrm{AM}$ & $1.75 \pm 0.04 \mathrm{c}$ & $0.80 \pm 0.11 \mathrm{bc}$ & $0.98 \pm 0.07 \mathrm{~d}$ & $0.78 \pm 0.03 \mathrm{c}$ \\
\hline \multirow{2}{*}{ Drought (D) } & $-\mathrm{AM}$ & $0.42 \pm 0.09 \mathrm{a}$ & $0.17 \pm 0.01 \mathrm{a}$ & $0.22 \pm 0.05 \mathrm{ab}$ & $0.13 \pm 0.01 \mathrm{a}$ \\
& $+\mathrm{AM}$ & $0.48 \pm 0.01 \mathrm{a}$ & $0.18 \pm 0.04 \mathrm{a}$ & $0.38 \pm 0.07 \mathrm{~b}$ & $0.29 \pm 0.04 \mathrm{~b}$ \\
\hline
\end{tabular}

Different lower-case letters within the same column indicate significant differences

Significantly higher fresh and dry shoots and fresh roots biomass were obtained in the inoculated plants (+AM) under control, salt and high temperature stress conditions compared to the non-mycorrhizal ones (-AM) (Table 3). Beneficial effects of AM fungi to target plant including enhanced nutrient uptake mostly phosphorus and water uptake, thereby stimulating the growth of the plant are well known (Bowles et al., 2016). Salt stress causes interfere in the homeostasis of the ions wherewith reactive oxygen species release in the plant cell. By the fact that AM fungi reduces the negative effects of salt stress by hyphae network, it promotes the growth of the plant (Wu et al., 2010). However, in this study the mycorrhizal plants under drought condition did not keep higher shoot biomass compared to non-mycorrhizal ones, which can be related to carbon drain effect or dysfunction of maize metabolism (Liu et al., 2004) and correlated with results were reported by Kohler et al. (2008) and Zhu et al. (2012).

Table 3. Biomass of mycorrhizal $(+A M)$ and non-mycorrhizal $(-A M)$ plants after 42 days of growth

\begin{tabular}{|c|c|c|c|c|c|}
\hline \multicolumn{2}{|c|}{ Age of plant 42 days } & \multicolumn{2}{|c|}{ Shoots } & \multicolumn{2}{|c|}{ Roots } \\
\hline \multicolumn{2}{|l|}{ Treatments } & $\begin{array}{l}\text { Fresh weight } \\
\left(\text { g plant }^{-1}\right)\end{array}$ & $\begin{array}{l}\text { Dry weight } \\
\left(\mathrm{g} \text { plant }^{-1}\right)\end{array}$ & $\begin{array}{l}\text { Fresh weight } \\
\left(\text { g plant }^{-1}\right)\end{array}$ & $\begin{array}{l}\text { Dry weight } \\
\left(\text { g plant }^{-1}\right)\end{array}$ \\
\hline \multirow{2}{*}{ Control (C) } & $-\mathrm{AM}$ & $4.27 \pm 0.11 \mathrm{c}$ & $2.66 \pm 0.27 b$ & $1.50 \pm 0.17 \mathrm{~d}$ & $0.69 \pm 0.03 d$ \\
\hline & $+\mathrm{AM}$ & $6.06 \pm 0.21 \mathrm{~d}$ & $3.70 \pm 0.11 \mathrm{c}$ & $3.29 \pm 0.19 \mathrm{e}$ & $1.61 \pm 0.06 \mathrm{e}$ \\
\hline \multirow{2}{*}{ Salt (S) } & $-\mathrm{AM}$ & $0.84 \pm 0.08 \mathrm{a}$ & $0.43 \pm 0.01 \mathrm{a}$ & $0.20 \pm 0.06 \mathrm{a}$ & $0.13 \pm 0.03 a$ \\
\hline & $+\mathrm{AM}$ & $1.23 \pm 0.16 \mathrm{~b}$ & $0.69 \pm 0.01 \mathrm{a}$ & $0.62 \pm 0.09 \mathrm{bc}$ & $0.35 \pm 0.05 b$ \\
\hline \multirow{2}{*}{ High temperature (HT) } & $-\mathrm{AM}$ & $4.37 \pm 0.15 \mathrm{c}$ & $2.70 \pm 0.23 b$ & $1.52 \pm 0.17 \mathrm{~d}$ & $0.67 \pm 0.04 d$ \\
\hline & $+\mathrm{AM}$ & $6.04 \pm 0.17 \mathrm{~d}$ & $3.76 \pm 0.08 \mathrm{c}$ & $3.27 \pm 0.22 \mathrm{e}$ & $1.60 \pm 0.07 \mathrm{e}$ \\
\hline \multirow{2}{*}{ Drought (D) } & $-\mathrm{AM}$ & $0.75 \pm 0.05 \mathrm{a}$ & $0.52 \pm 0.04 \mathrm{a}$ & $0.27 \pm 0.06 \mathrm{ab}$ & $0.10 \pm 0.02 \mathrm{a}$ \\
\hline & $+\mathrm{AM}$ & $1.01 \pm 0.08 \mathrm{ab}$ & $0.78 \pm 0.12 \mathrm{a}$ & $0.75 \pm 0.02 \mathrm{c}$ & $0.49 \pm 0.02 c$ \\
\hline
\end{tabular}

Different lower-case letters within the same column indicate significant differences

One of the earliest responses in plants by the colonization of AM fungi is the rapid accumulation of reactive oxygen species (ROS) (Choudhury et al., 2017). ROS is not 
only harmful to plant cells, but also to mycorrhizal fungi. Under different stress conditions at different rates of enhanced enzyme activities together with gene expressions were found among various treatments. Changing in the activities of antioxidant enzymes as peroxidase, catalase etc. are not exclusive specificity of arbuscular mycorrhizal fungi during colonization process, presumably playing the key role the specific feature of each strain, instead of the colonization.

Catalase is playing a role in the production of monomers, dimers and phenoxy-free radicals and regulates the harmful accumulation of hydrogen peroxide $\left(\mathrm{H}_{2} \mathrm{O}_{2}\right)$. In general, higher CAT enzyme activity of non-mycorrhizal plants were measured under different stresses compared to mycorrhizal plants after 21 days of growth. Reverse tendency was observed in CAT enzyme activity under salt and high temperature stresses at older plants (Fig. $1 c, d)$.
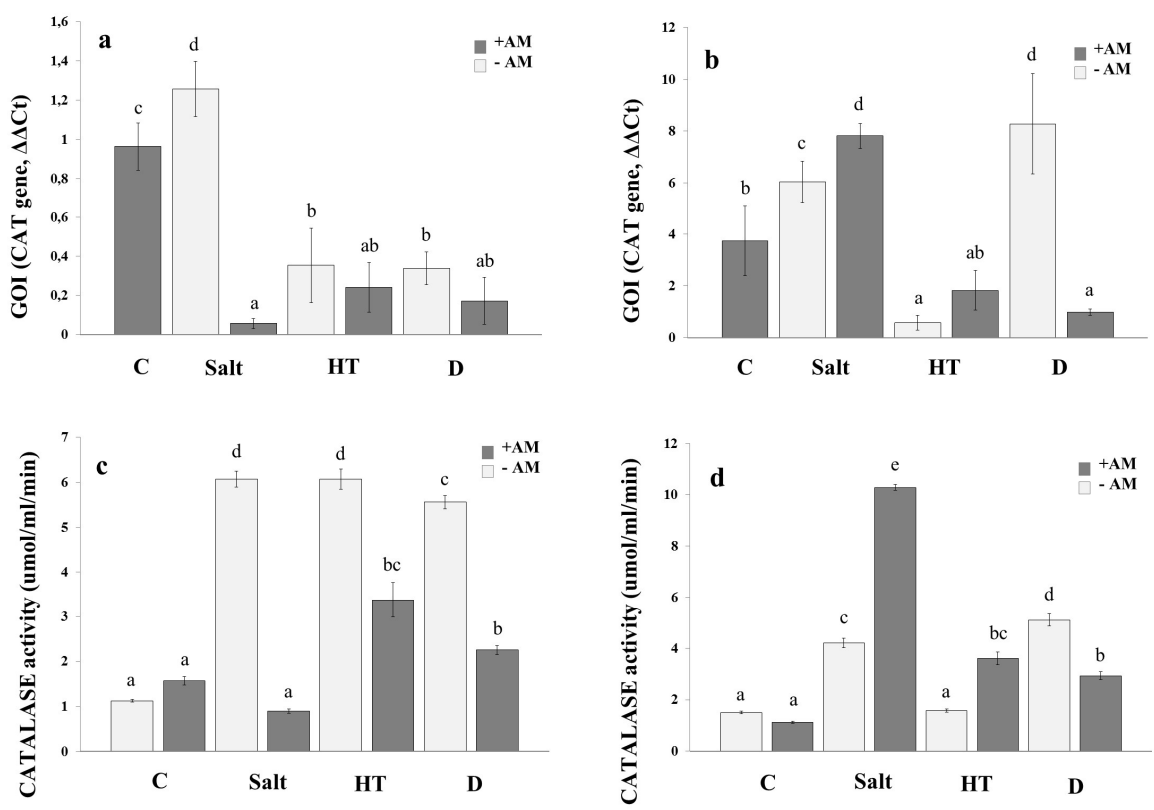

Figure 1. Catalase gene expression and enzyme activity of mycorrhizal and non-mycorrhizal plants under different stress conditions. a) CAT gene expression in 21-day-old plant b) CAT gene expression in 42-day-old plant c) CAT enzyme activity in 21-day-old plant d) CAT enzyme activity in 42-day-old plant; different letters represent significantly different $(p<0.05)$ values

At an early stage of plant, mycorrhizal fungi often seems to parasites, which due to the not sufficient production of energy from plant photosynthesis to cover the growth of mycorrhizal fungi together with plant requirement. Without stress the mycorrhizal and non-mycorrhizal control plants showed same enzyme activity. Under stress conditions at early-growth stages of mycorrhizal plants could produce less energy to respond. This could be one of the reasons for the lower enzyme activity of mycorrhizal plants compared to non-mycorrhizal ones after 21 days of growth. In line with the progressing of the incubation time leaf surface increases, plants produce more energy which can be used by both the production of enzymes and by the fungi for growth. As detected during salt and high temperature stress conditions in mycorrhizal plants after 42 days of growth compared to non-mycorrhizal ones. Similar tendency was found measuring 1.3 times higher $C A T$ gene expression under salt stress after 42 days of growth. Our results, 
regarding increased catalase enzyme activity under salt stress condition are agreed with the results of AbdElgawad et al (2016) and Chaparzadeh et al. (2004) who treated Calendula officinalis with $100 \mathrm{mM} \mathrm{NaCl}$ solution. Higher enzyme activity under salt and high temperature stresses in inoculated older plants are often found (Zhu et al., 2010). Under drought stress condition, non-mycorrhizal plants showed higher enzymatic activity at both age of plants. Due to the increased uptake of water resulting from higher AM fungi colonization rate could moderate the drought effect during 42-days term stress. The tendency of gene expression under drought stress was the same as the results of enzyme activity and besides in 21 days old plants no significant difference was observed (Fig. 1a). However, significantly higher (7.8 times) gene expression was measured in 42 days old non-mycorhizal plants under drought condition compared to inoculated ones (Fig. 1b).

The increased PER activity of plants can occur not only in mycorrhizal plants but also during various abiotic stresses (Borde et al., 2011; Rahmaty and Khara, 2011; Pfeiffer et al., 2013). Interestingly, non-mycorrhizal plants after 42 days of growth had higher peroxidase enzyme activity compared to the inoculated ones under high temperature (Fig. 2d).
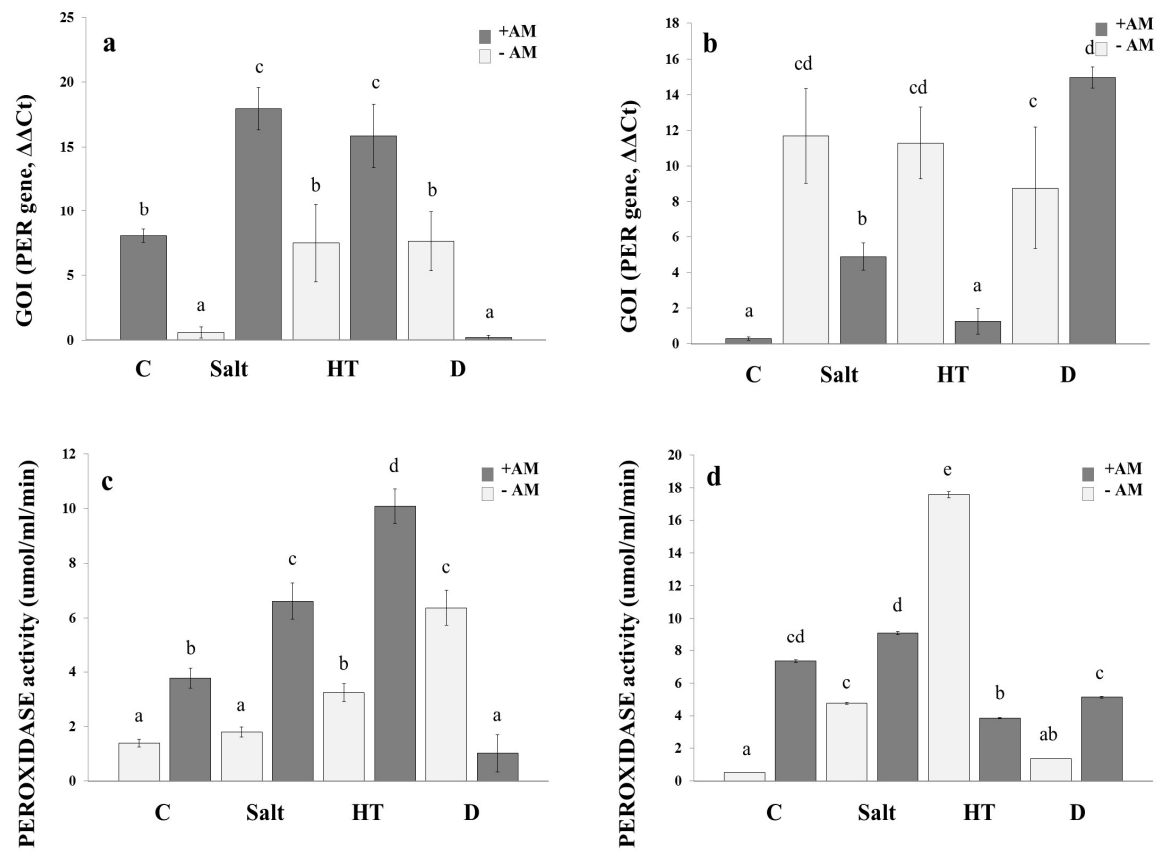

Figure 2. Peroxidase gene expression and enzyme activity of mycorrhizal and non-mycorrhizal plants under different stress conditions. a) PER gene expression in 21-day-old plant b) PER gene expression in 42-day-old plant c) PER enzyme activity in 21-day-old plant d) PER enzyme activity in 42-day-old plant; different letters represent significantly different $(p<0.05)$ values

Different results of enzymes activities reported during the colonization of AM fungi indicating that the enzyme activity are somehow connect to the symbiotic processes (Younesi et al., 2013). After 21 days of growth inoculated plants demonstrated higher enzyme activity and gene expression under salt ( 3 times) and high temperature stresses (2.8 times) compared to non-mycorrhizal ones (Fig. 2a,c). At the age of 42-day old mycorrhizal plants showed higher enzyme activity under salt and drought stress 
compared to non-mycorrhizal treated plants. Under high temperature stress, nonmycorrhizal plants showed higher activity and gene expression than the inoculated ones (Fig. 2b,d). Stomatal conductance and transpiration rates of colonized plants are higher than non-colonized ones under high temperature stress, indicating that AM fungi colonization play a role in the gas exchange metabolism improvement with open stoma and increase the rate of transpiration (Zhu et al., 2010). During temperature stress symbiosis improves water retention, preventing the plant of the negative effects of dehydration (Zhu et al., 2012).

Under control condition after 21 and 42 days of incubation, there was no difference in CAT activity regardless of mycorrhization compared to the higher PER activity in mycorrhizal plants. However, under salt stress CAT activity of 21 days old mycorrhizal plants is lower (Fig. 1a,c) than PER activity (Fig. 2a,c). This strategy of an early stage of plant most likely due to the activity and role function of PER and CAT in the plant defense system. Both are involved in the degradation of $\mathrm{H}_{2} \mathrm{O}_{2}$, besides Estrada et al. (2013) and Abeer et al. (2015) observed in mycorrhizal plants exhibited much higher activity of PER than CAT enzyme in the elimination of $\mathrm{H}_{2} \mathrm{O}_{2}$.

Glutathione S-transferases are among the most well-known and most frequently used detoxification enzymes (Nianiou-Obeidat et al., 2017). They play a role in the inactivation of oxidative stress metabolites, which process protects the cell from oxidative damages (Mohsenzadeh et al., 2011). GST in plants neutralize not only toxic substances but also promote a number of defensive mechanisms in the plant. It may facilitate the intracellular storage and transport of hydrophobic non-substrate compounds such as metabolites. Under the various stresses there were no significant differences in GST enzyme activity between mycorrhizal and non-mycorrhizal plants after 21 days of growth (Fig. 3c).
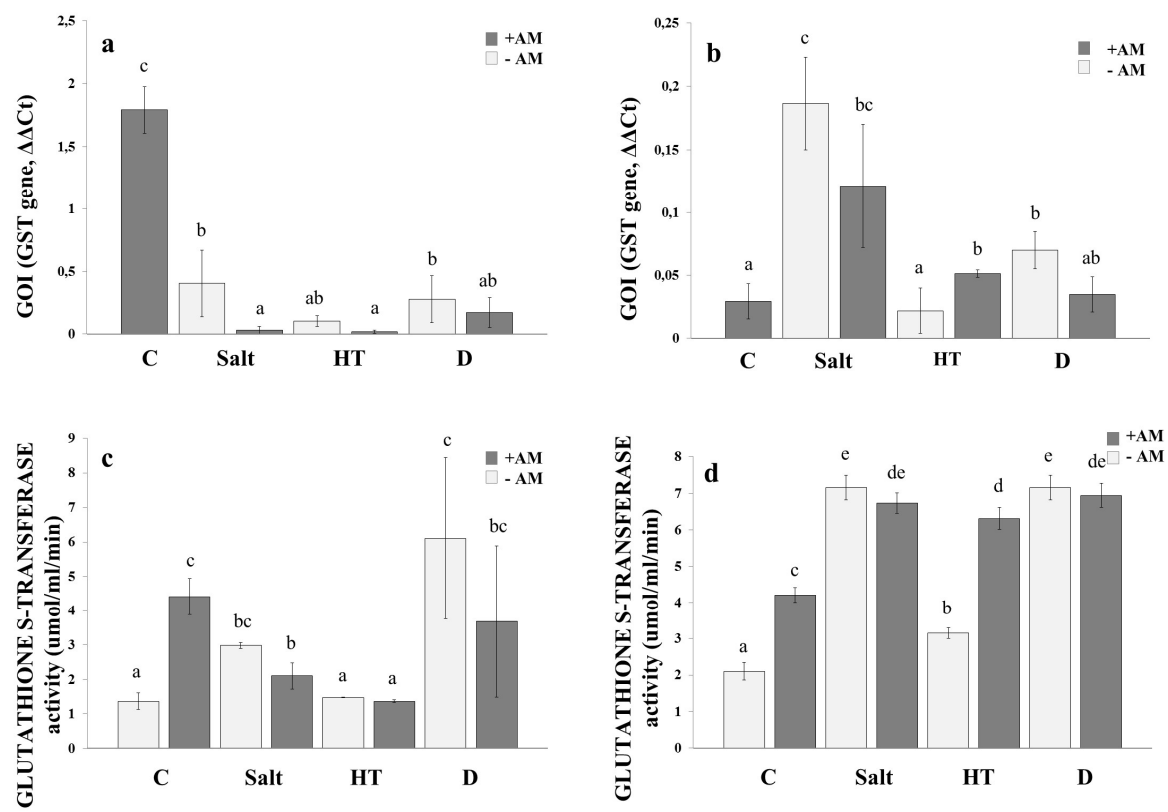

Figure 3. Glutathione S-transferase gene expression and enzyme activity of mycorrhizal and non-mycorrhizal plants under different stress conditions. a) GST gene expression in 21-day-old plant b) GST gene expression in 42-day-old plant c) GST enzyme activity in 21-day-old plant d) GST enzyme activity in 42-day-old plant; different letters represent significantly different ( $p<$ $0.05)$ values 
By the increase of incubation time all the stress effects induced higher enzyme activity in the plant compared to the control, which trend was previously reported by Haluskova et al. (2009). Depending on the age of the plants Wagner et al. (2002) found also different $G S T$ gene expression under different stress conditions similar to our results (Fig. 3a,b). In the present study, the GST gene expression and the GST enzyme activity showed the same tendency under high temperature after 42 days of growth in agreement with the studies of Cetinkaya et al. (2014) and Mayer et al. (2017) (Fig. 3b,d).

After three weeks of incubation drought stress induced significantly increased enzyme activity in mycorrhizal plants (Fig. 4c). The enzyme activity of PPO is increased in general with the age of the plants. In this study the changes in $P P O$ gene expression correlated with the enyzme activity under different stress conditions (Fig. 4a,c). Different stresses caused various changes in enzyme activities but only salt stress increased at high rate ( 8 times) of this enzyme accumulation in mycorrhizal plant after 42 days of growth (Fig. 4b,d). The higher polyphenol oxidase activity under salt stress was also observed by Kaya et al. (2013b) and Demir and Kocacaliskan (2001).
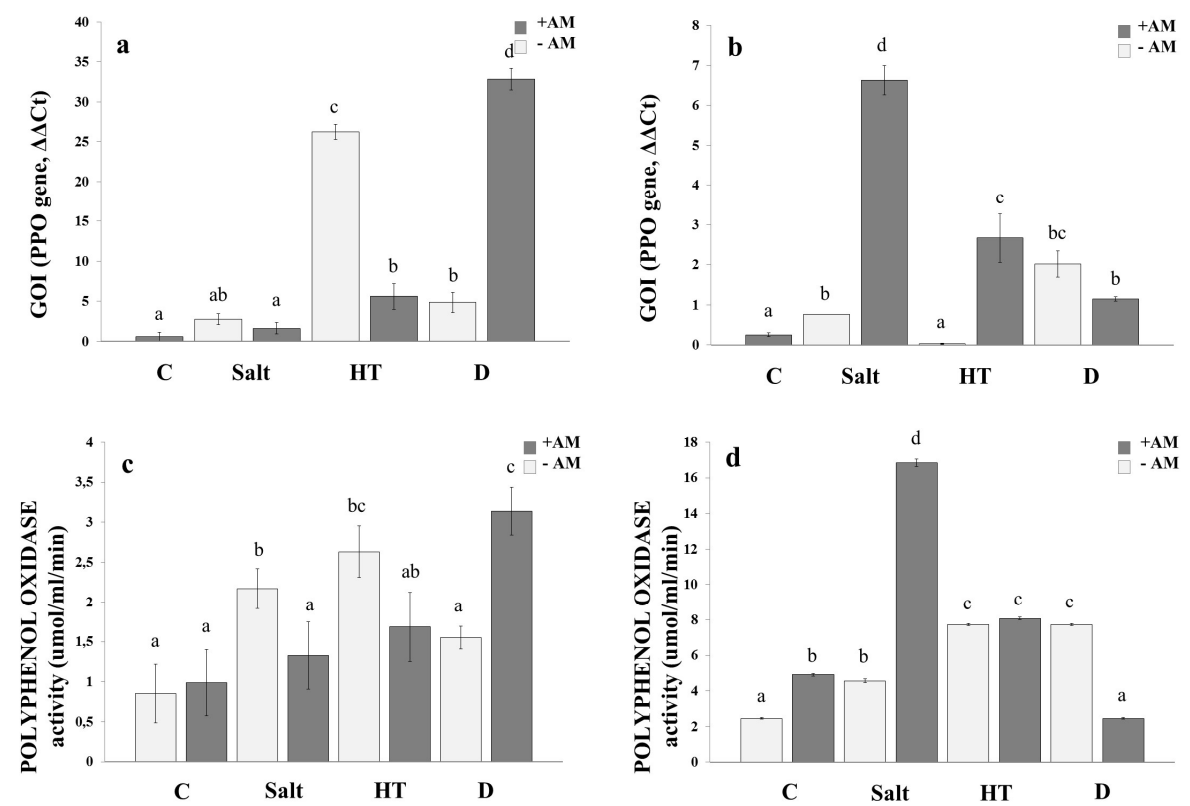

Figure 4. Polyphenol oxidase gene expression and enzyme activity of mycorrhizal and nonmycorrhizal plants under different stress conditions. a) PPO gene expression in 21-day-old plant b) PPO gene expression in 42-day-old plant c) PPO enzyme activity in 21-day-old plant d) $P P O$ enzyme activity in 42-day-old plant; different letters represent significantly different $(p<$ $0.05)$ values

Our result suggests that measured defense enzymes are working together in a complex network, influencing to each others. At an early stage of inoculation, when low colonization level but active arbuscule formation could be observed in mycorrhizal plants the highest accumulation of tested enzymes altogether were measured in nonmycorrhizal plants under drought stress. It is almost two times more, than measured in mycorrhizal plants. It shows opposite tendency than expected from mycorrhizae offered balance activity under stresses. Explaination of less damage caused in mycorrhizal plant 
than in non-mycorrhizal one under drought condition most likely due to the increased surface offered by external hyphae of mycorrhizal fungi increase the water uptake and water efficiency (Smith and Read, 2010; Zhao et al., 2015). It could be one reason for lower defense enzyme activities measured in mycorrhizal treatment under dry condition. Similar tendency was found applying salt stress, when the mycelium network of AM fungi could also attenuate the strength of this stress using different mechanisms (Mardukhi et al., 2015). Out of the tested stresses, the high temperature caused the biggest change in measured defense enzymes between mycorrhizal and non-mycorrhizal treatments.

\section{Conclusions}

Our results suggest that AM inoculation could take part in the alleviation processes caused by high temperature, salt and drought stresses. However, these mechanisms are influenced by the age of the plants which is most likely justified by energy considerations. Besides increased defense enzymes activities of mycorrhizal plants compared to non-mycorrhizal one, the AM fungi could offer some other strategies to increased tolerance of plants against salt and drought stresses. Nevertheless, the activity of CAT, PER, GST and PPO concerning degradation of toxic ROS molecules in plant defense system under various stresses, should be investigated in more detail. Especially the CAT and PER related expression system and not well documented PPO activity supports further studies in plant - AM fungi symbiotic relationship.

Acknowledgements. This work was supported by „ÚNKP-17-3 New National Excellence Program of the Ministry of Human Capacities", "GLIA: 2017-1.3.1-VKE-2017 has been implemented with the support provided from the National Research, Development and Innovation Fund of Hungary, financed under the 00030 funding scheme” and „Higher Education Institutional Excellence Program (1783-3/2018/FEKUTSTRAT) awarded by the Ministry of Human Capacities within the framework of water related researches of Szent István University”.

\section{REFERENCES}

[1] AbdElgawad, H., Zinta, G., Hegab, M., Pandey, R., Asard, H., Abuelsoud, W. (2016): High salinity induces different oxidative stress and antioxidant responses in maize seedling organs. - Front. Plant. Sci. 24: 134-141.

[2] Abdel Latef, A. A. H. (2013): Growth and some physiological activities of pepper (Capsicum annuum L.) in response to cadmium stress and mycorrhizal symbiosis. - J. Agr. Sci. Tech. 15: 1437-1448.

[3] Abeer, H., Abd_Allah, E. F., Alqarawi, A. A., El-Didamony, G., Alwhibi, M., Egamberdieva, D., Ahmad, P. (2014): Alleviation of adverse impact of salinity on faba bean (Vicia faba L.) by arbuscular mycorrhizal fungi. - Pak. J. Bot. 46(6): 2003-2013.

[4] Aebi, H. (1984): Catalase in vitro. - Method. Enzymol. 105: 121-126.

[5] Anjum, S. A., Xie, X. Y., Wang, L. C., Saleem, M. F., Man, C., Lei, W. (2011): Morphological, physiological and biochemical responses of plants to drought stress. Afr. J. Agric. Res. 6(9): 2026-2032.

[6] Anjum, S. A., Tanveer, M., Ashraf, U., Hussain, S., Shahzad, B., Khan, I., Wang, L. (2016): Effect of progressive drought stress on growth, leaf gas exchange, and antioxidant production in two maize cultivars. - Environ. Sci. Pollut. R. 23: 17132-17141. 
[7] Azcón, R., Barea, J. M. (2010): Mycorrhizosphere interactions for legume improvement. - In: Microbes for legume improvement. Springer, Vienna, pp. 237-271.

[8] Baslam, M., Goicoechea, N. (2012): Water deficit improved the capacity of arbuscular mycorrhizal fungi (AMF) for inducing the accumulation of antioxidant compounds in lettuce leaves. - Mycorrhiza 22: 347-359.

[9] Borde, M., Dudhane, M., Jite, P. (2011): Growth photosynthetic activity and antioxidant responses of mycorrhizal and non-mycorrhizal bajra (Pennisetum glaucum) crop under salinity stress condition. - Crop Prot. 30: 265-271.

[10] Bowles, T. M., Barrios-Masias, F. H., Carlisle, E. A., Cavagnaro, T. R., Jackson, L. E. (2016): Effects of arbuscular mycorrhizae on tomato yield, nutrient uptake, water relations, and soil carbon dynamics under deficit irrigation in field conditions. - Sci. Total Environ. 566: 1223-1234.

[11] Bradford, M. (1976): A rapid and sensitive method for the quantitation of microgram quantities of protein utilizing the principle of protein-dye binding. - Anal. Biochem. 72: 248-254.

[12] Cameron, D. D., Neal, A. L., van Wees, S. C., Ton, J. (2013): Mycorrhiza-induced resistance: more than the sum of its parts? - Trends Plant Sci. 18: 539-545.

[13] Carrasco-Ríos, L., Pinto, M. (2014): Effect of salt stress on antioxidant enzymes and lipid peroxidation in leaves in two contrasting corn, 'Lluteño' and 'Jubilee'. - Chilean J. Agr. Res. 74: 89-95.

[14] Cetinkaya, H., Tasci, E., Dinler, B. S. (2014): Regulation of glutathione S-transferase enzyme activity with salt pre-treatment under heat stress in maize leaves. - Res. Plant Biol. 4: 5.

[15] Chaparzadeh, N., D’Amico, M. L., Khavari-Nejad, R. A., Izzo, R., Navari-Izzo, F. (2004): Antioxidative responses of Calendula officinalis under salinity conditions. - Plant Physiol. Bioch. 42: 695-701.

[16] Chen, S., Jin, W., Liu, A., Zhang, S., Liu, D., Wang, F., Lin, X., He, C. (2013): Arbuscular mycorrhizal fungi (AMF) increase growth and secondary metabolism in cucumber subjected to low temperature stress. - Sci. Hortic-Amsterdam 160: 222-229.

[17] Choudhury, F. K., Rivero, R. M., Blumwald, E., Mittler, R. (2017): Reactive oxygen species, abiotic stress and stress combination. - Plant J. 90: 856-867.

[18] Chugh, V., Kaur, N., Gupta, A. K. (2011): Evaluation of oxidative stress tolerance in maize (Zea mays L.) seedlings in response to drought. - Indian J. Biochem Bio. 48: 4753.

[19] Dehghan, G., Amjad, L., Nosrati, H. (2013): Enzymatic and non-enzymatic antioxidant responses of alfalfa leaves and roots under different salinity levels. - Acta Biol. Hung. 64: 207-217.

[20] Demiİr, Y., Kocaçalişkan, İ. (2001): Effects of $\mathrm{NaCl}$ and proline on polyphenol oxidase activity in bean seedlings. - Biol. Plantarum 44: 607-609.

[21] Estrada, B., Aroca, R., Barea, J. M., Ruiz-Lozano, J. M. (2013): Native arbuscular mycorrhizal fungi isolated from a saline habitat improved maize antioxidant systems and plant tolerance to salinity. - Plant Sci. 201: 42-51.

[22] Feddermann, N., Finlay, R., Boller, T., Elfstrand, M. (2010): Functional diversity in arbuscular mycorrhiza - the role of gene expression, phosphorous nutrition and symbiotic efficiency. - Fungal Ecol. 3: 1-8.

[23] Fehrmann, H., Dimond, A. E. (1967): Peroxidase activity and phytophthora resistance in different organs of the potato plant. - Phytopathology 57: 69-72.

[24] Forieri, I., Hildebrandt, U., Rostás, M. (2016): Salinity stress effects on direct and indirect defence metabolites in maize. - Environ. Exp. Bot. 122: 68-77.

[25] Giovannetti, M., Mosse, B. (1980): An evaluation of techniques for measuring vesicular arbuscular mycorrhizal infection in roots. - New Phytol. 84: 489-500.

[26] Habig, W. H., Pabst, M. J., Jakoby, W. B. (1974): Glutathione S-transferases the first enzymatic step in mercapturic acid formation. - J. Biol. Chem. 249: 7130-7139. 
[27] Hajiboland, R., Aliasgharzadeh, N., Laiegh, S., Poschenrieder, C. (2010): Colonization with arbuscular mycorrhizal fungi improves salinity tolerance of tomato (Solanum lycopersicum L.) plants. - Plant Soil 331: 313-327.

[28] Halušková, L. U., Valentovičová, K., Huttová, J., Mistrík, I., Tamás, L. (2009): Effect of abiotic stresses on glutathione peroxidase and glutathione S-transferase activity in barley root tips. - Plant Physiol. Biochem. 47(11-12): 1069-1074.

[29] Kaya, C., Ashraf, M., Dikilitas, M., Tuna, A. L. (2013a): Alleviation of salt stressinduced adverse effects on maize plants by exogenous application of indoleacetic acid (IAA) and inorganic nutrients-A field trial. - Aust. J. Crop Sci. 7(2): 249.

[30] Kaya, C., Sonmez, O., Aydemir, S., Ashraf, M., Dikilitas, M. (2013b): Exogenous application of mannitol and thiourea regulates plant growth and oxidative stress responses in salt-stressed maize (Zea mays L.). - J. Plant Interact. 8: 234-241.

[31] Kohler, J., Hernández, J. A., Caravaca, F., Roldán, A. (2008): Plantgrowth-promoting rhizobacteria and arbuscular mycorrhizal fungi modify alleviation biochemical mechanisms in water- stressed plants. - Funct. Plant Biol. 35: 141-151.

[32] Liu, A., Wang, B., Hamel, C. (2004): Arbuscular mycorrhiza colonization and development at suboptimal root zone temperature. - Mycorrhiza 14: 93-101.

[33] Liu, T., Sheng, M., Wang, C. Y., Chen, H., Li, Z., Tang, M. (2015): Impact of arbuscular mycorrhizal fungi on the growth, water status, and photosynthesis of hybrid poplar under drought stress and recovery. - Photosynthetica 53: 250-258.

[34] Lobell, D. B., Sibley, A., Ortiz-Monasterio, J. I. (2012): Extreme heat effects on wheat senescence in India. - Nature Climate Change 2: 186-189.

[35] Mardukhi, B., Rejali, F., Daei, G., Ardakani, M. R., Malakouti, M. J., Miransari, M. (2015): Mineral uptake of mycorrhizal wheat (Triticum aestivum L.) under salinity stress. Commun. - Soil Sci. Plan. 46: 343-357.

[36] Mayer, Z., Duc, N. H., Sasvári, Z., Posta, K. (2017): How arbuscular mycorrhizal fungi influence the defense system of sunflower during different abiotic stresses. - Acta Biol. Hung. 68: 376-387.

[37] Mohsenzadeh, S., Esmaeili, M., Moosavi, F., Shahrtash, M., Saffari, B., Mohabatkar, H. (2011): Plant glutathione S-transferase classification, structure and evolution. - Afr. J. Biotechnol. 10: 8160-8165.

[38] Molazem, D., Azimi, J. (2015): Morpho-physiological characterization in eight varieties of maize (Zea mays L.) under soil salinity. - Pol. J. Environ. Stud. 24: 6.

[39] Nagy, J. (2010): Impact of fertilization and irrigation on the correlation between the soil plant analysis development value and yield of maize. - Commun. Soil Sci. Plant Anal. 41(11): 1293-1305.

[40] Nianiou-Obeidat, I., Madesis, P., Kissoudis, C., Voulgari, G., Chronopoulou, E., Tsaftaris, A., Labrou, N. E. (2017): Plant glutathione transferase-mediated stress tolerance: functions and biotechnological applications. - Plant Cell Rep. 36: 791-805.

[41] Păun, A., Neagoe, A., Păun, M., Baciu, I., Iordache, V. (2015): Heavy metal-induced differential responses to oxidative stress and protection by mycorrhization in sunflowers grown in lab and field scales. - Pol. J. Environ. Stud. 24(3).

[42] Pepó, P., Vári, E. (2016): Evaluation of the yield production of C3 (Triticum aestivum L.) and C4 (Zea mays L.) cereals with a new plant physiological parameter. - J. Anim. Plant. Sci. 26(3): 716-724.

[43] Pfeiffer, T., Štolfa, I., Žanić, M., Pavičić, N., Cesar, V., Lepeduš, H. (2013): Oxidative stress in leaves of two olive cultivars under freezing conditions. - Acta Biol. Hung. 64: 341-351.

[44] Pozo, M. J., Azcón-Aguilar, C. (2007): Unravelling mycorrhiza-induced resistance. Curr. Opin. Plant Biol. 10: 393-398.

[45] Rahmaty, R., Khara, J. (2011): Effects of vesicular arbuscular mycorrhiza Glomus intraradices on photosynthetic pigments, antioxidant enzymes, lipid peroxidation, and 
chromium accumulation in maize plants treated with chromium. - Turkish J. Biol. 35: 5158.

[46] Rathmell, W. G., Sequeira, L. (1974): Soluble peroxidase in fluid from the intercellular spaces of tobacco leaves. - Plant Physiol. 53: 317-318.

[47] R Core Team (2011): R: A language and environment for statistical computing. - R Foundation for Statistical Computing, Vienna, Austria. https://www.r-project.org/.

[48] Ruiz-Sánchez, M., Aroca, R., Munoz, Y., Armada, E., Polón, R., Ruiz-Lozano, J. M. (2010): The arbuscular mycorrhizal symbiosis enhances the photosynthetic efficiency and the antioxidative response of rice plants subjected to drought stress. - J. Plant Physiol. 167(11): 862-869.

[49] Shi, J., Yan, B., Lou, X., Ma, H., Ruan, S. (2017): Comparative transcriptome analysis reveals the transcriptional alterations in heat-resistant and heat-sensitive sweet maize (Zea mays L.) varieties under heat stress. - BMC Plant Biol. 17(1): 26.

[50] Smith, S. E., Read, D. J. (2010): Mycorrhizal symbiosis. - Academic press.

[51] Smith, S. E., Smith, F. A. (2011): Roles of arbuscular mycorrhizas in plant nutrition and growth: new paradigms from cellular to ecosystems scales. - Annu. Rev. Plant Biol. 62: 227-250.

[52] Smith, S. E., Jakobsen, I., Grønlund, M., Smith, F. A. (2011): Roles of arbuscular mycorrhizas in plant phosphorus nutrition: interactions between pathways of phosphorus uptake in arbuscular mycorrhizal roots have important implications for understanding and manipulating plant phosphorus acquisition. - Plant Physiol. 156: 1050-1057.

[53] Song, K., Kim, H. C., Shin, S., Kim, K. H., Moon, J. C., Kim, J. Y., Lee, B. M. (2017): Transcriptome analysis of flowering time genes under drought stress in maize leaves. Front. Plant. Sci. 8: 267.

[54] Vierheilig, H., Coughlan, A. P., Wyss, U., Piché, Y. (1998): Ink and vinegar, a simple staining technique for arbuscular-mycorrhizal fungi. - Appl. Environ. Microb. 64: 50045007.

[55] Vos, C., Schouteden, N., van Tuinen, D., Chatagnier, O., Elsen, A., de Waele, D., Panis, B., Gianinazzi-Pearson, V. (2013): Mycorrhiza-induced resistance against the root knot nematode Meloidogyne incognita involves priming of defense gene responses in tomato. - Soil Biol. Biochem. 60: 45-54.

[56] Wagner, U., Edwards, R., Dixon, D. P., Mauch, F. (2002): Probing the diversity of the Arabidopsis glutathione S-transferase gene family. - Plant Mol. Biol. 49: 515-532.

[57] Wu, Q. S., Zou, Y. N. (2010): Beneficial roles of arbuscular mycorrhizas in citrus seedlings at temperature stress. - Sci. Hortic. 125: 289-293.

[58] Younesi, O., Moradi, A., Namdari, A. (2013): Influence of arbuscular mycorrhiza on osmotic adjustment compounds and antioxidant enzyme activity in nodules of saltstressed soybean (Glycine max). - Acta Agri. Sloven. 101(2): 219.

[59] Zenda, T., Liu, S., Wang, X., Jin, H., Liu, G., Duan, H. (2018): Comparative proteomic and physiological analyses of two divergent maize inbred lines provide more insights into drought-stress tolerance mechanisms. - Int. J. Mol. Sci. 19(10): 3225.

[60] Zhao, R., Guo, W., Bi, N., Guo, J., Wang, L., Zhao, J., Zhang, J. (2015): Arbuscular mycorrhizal fungi affect the growth, nutrient uptake and water status of maize (Zea mays L.) grown in two types of coal mine spoils under drought stress. - Appl. Soil Ecol. 88: 41-49.

[61] Zhu, X. C., Song, F. B., Xu, H. W. (2010): Influence of arbuscular mycorrhizae on lipid peroxidation and antioxidant enzyme activity of maize plants under temperature stress. Mycorrhiza 20: 325-332.

[62] Zhu, X. C., Song, F. B., Liu, S. Q., Liu, T. D., Zhou, X. (2012): Arbuscular mycorrhizae improves photosynthesis and water status of Zea mays L. under drought stress. - Plant Soil Environ 58: 186-191. 